University of Nebraska - Lincoln

DigitalCommons@University of Nebraska - Lincoln

May 2002

\title{
Hybosorids of the United States and Expanding Distribution of the Introduced Species Hybosorus illigeri (Coleoptera: Scarabaeoidea: Hybosoridae)
}

\author{
Federico C. Ocampo \\ University of Nebraska - Lincoln, focampo2@unl.edu
}

Follow this and additional works at: https://digitalcommons.unl.edu/entomologypapers

Part of the Entomology Commons

Ocampo, Federico C., "Hybosorids of the United States and Expanding Distribution of the Introduced Species Hybosorus illigeri (Coleoptera: Scarabaeoidea: Hybosoridae)" (2002). Papers in Entomology. 123. https://digitalcommons.unl.edu/entomologypapers/123

This Article is brought to you for free and open access by the Museum, University of Nebraska State at DigitalCommons@University of Nebraska - Lincoln. It has been accepted for inclusion in Papers in Entomology by an authorized administrator of DigitalCommons@University of Nebraska - Lincoln. 


\title{
Hybosorids of the United States and Expanding Distribution of the Introduced Species Hybosorus illigeri (Coleoptera: Scarabaeoidea: Hybosoridae)
}

\author{
F. C. OCAMPO ${ }^{1}$
}

Systematics Research Collections, University of Nebraska State Museum, W 436 Nebraska Hall, Lincoln, NE 68588-0546

Ann. Entomol. Soc. Am. 95(3): 316-322 (2002)

\begin{abstract}
Two species of Hybosoridae, Hybosorus illigeri Reiche and Pachyplectrus laevis LeConte, are distributed in the United States. For the introduced species H. illigeri, three new country records are reported (Dominican Republic, Nicaragua, and Venezuela); six new state records are recorded in the United States (Arkansas, Arizona, Kansas, Missouri, New Mexico, and Virginia); and 10 new state records are reported in Mexico (Baja California Sur, Chiapas, Michoacán, Nuevo León, Sinaloa, Sonora, Tamaulipas, Veracruz, Querétaro, and Yucatán). Information on the predatory habits of $H$. illigeri and a report as a turfgrass pest in the state of Arizona are provided. Pachyplectrus laevis is redescribed, and information on its biology and distribution is provided. A key to the species is provided along with diagnostic illustrations.
\end{abstract}

RESUMEN Dos especies de Hybosoridae, Hybosorus illigeri Reiche y Pachyplectrus laevis LeConte se distribuyen en los Estados Unidos. Se reporta para la especie introducida, Hybosorus illigeri, nuevos registros en tres paises (República Dominicana, Nicaragua y Venezuela); seis nuevos registros en estados de los Estados Unidos (Arkansas, Arizona, Kansas, Missouri, New Mexico, y Virginia); y diez nuevos registros en estados de Mexico (Baja California Sur, Chiapas, Michoacán, Nuevo León, Sinaloa, Sonora, Tamaulipas, Veracruz, Querétaro y Yucatán). Se provee información sobre los hábitos predadores de Hybosorus illigeri. Pachyplectrus laevis es redescripta y se provee información sobre su biología y distribución. Se provee una clave para las especies junto con ilustraciones para su diagnosis.

KEY WORDS Scarabaeoidea, Hybosoridae, Hybosorus, Pachyplectrus, New World, introduced species

The Hybosoridae is a small family within Scarabaeoidea, that includes 32 genera and $\approx 210$ species (Ocampo 2000). It is a cosmopolitan family that is best represented in the tropics. In adults, diagnostic characters are the prominent mandibles and labrum and the 9- or 10-segmented antennae with the first segment of the club usually hollowed to receive segments 2 and 3 (Fig. 1). Little is known about the biology of members of this family. Larvae of hybosorids are distinguished from other scarabs by the presence of stridulatory structures on both prothoracic and mesothoracic legs, and the presence of three truncate lobes on the anterior margin of the labrum (Ritcher 1966, Woodruff 1973). Larvae stridulate by rubbing the front legs against the anterior margin of the epipharynx, a trait unique to the Hybosoridae (Paulian 1939). Two genera and two species of hybosorids occur in the United States and Northern Mexico: Hybosorus illigeri Reiche and Pachyplectrus laevis LeConte.

\footnotetext{
${ }^{1}$ E-mail: focampo@unlserve.unl.edu.
}

Pachyplectrus is a monotypic genus endemic to the southwest United States. Pachyplectrus laevis is redescribed because the original description, as with many old descriptions, lacks the necessary details for correct identification of the species. Hybosorus illigeri was introduced on the East Coast of the United States about $200 \mathrm{yr}$ ago. In this article I report the expanding distribution of $H$. illigeri in the New World and discuss its predatory habits.

\section{Materials and Methods}

The results of this study were based on specimens from the following institutions, curators, and collections. The collections and their acronyms are as follows: AMNH, American Museum of Natural History, New York, NY (Lee Herman, Jr.); CASC, California Academy of Sciences, San Francisco, CA (D. Kavanaugh, R. Brett); CMNC: Canadian Museum of Nature, Ottawa, Canada (R. S. Anderson, F. Génier); CMNH; Carnegie Museum of Natural History, Pittsburgh, PA (J. Rawlins, R. Davidson); EMEC, Essig 


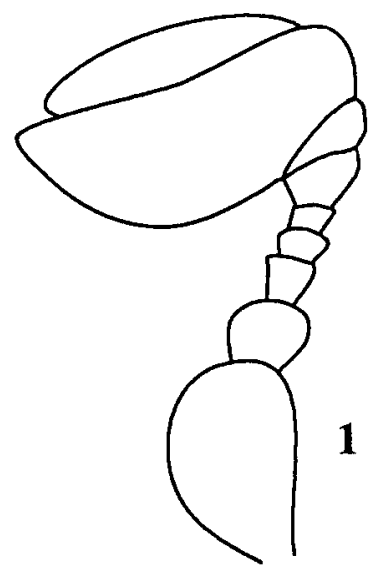

Fig. 1. Hybosorid typical antennal shape.

Museum of Entomology, University of California, Berkeley, CA (C. Barr); FMNH, Field Museum of Natural History, Chicago, IL (A. Newton); FSCA, Florida State Collection of Arthropods, Gainesville, FL (B. Beck, M. Thomas); HAHC, Henry and Anne Howden Collection, Ottawa, Canada (H. Howden); SEMC, Snow Entomological Museum, Lawrence, KS (S. Ashe, R. Brooks); TAMU, Texas A \& M University, College Station, TX (e.g., Riley); UMRM, W. R. Enns Entomology Museum, University of Missouri, Columbia, MO (R. Sites); CNCI, Canadian National Collection of Insects, Ottawa, Canada (A. Davies); UNSM, University of Nebraska State Museum, Lincoln, NE (B. Ratcliffe); USNM, United States National Museum, Washington, DC (at University of Nebraska).

\section{Key to Genera and Species of Hybosoridae from} North America and Northern Mexico

1. Antenna 10-segmented with 3-segmented club, first segment hollowed to receive segments 2 and 3 (Fig. 1). Mandibles and labrum

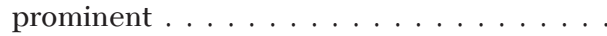
................ Hybosoridae, 2

$1^{\prime}$. Antenna not as above. Mandibles and labrum not prominent ...... Other Scarabaeoids

2. Frontoclypeal suture with medial, pyramidal tubercle (Fig. 3). Labrum without teeth. . . . . ......... Pachyplectrus laevis LeConte

2'. Frontoclypeal suture without medial tubercle (Fig. 2). Labrum with 7-11 teeth . . . . . . . ........... Hybosorus illigeri Reiche

\section{Hybosorus MacLeay 1819}

Type Species. Hybosorus illigeri Reiche 1853.

Hybosorus illigeri Reiche 1853

(Figs. 2, 4-6, 9)

Scarabaeus arator Illiger 1803: 210 (junior primary homonym).
Hybosorus oblongus Dahlbom (nomen oblitum).

Hybosorus pinguis Westwood 1845: 159 (nomen oblitum).

Hybosorus roei Westwood 1845: 159 (nomen oblitum). Hybosorus thoracicus Westwood 1845: 159 (nomen oblitum).

Hybosorus carolinus LeConte 1847: 84 (nomen oblitum).

Hybosorus illigeri Reiche 1853: 87.

Hybosorus nitidus Lansberge1882: 21.

Hybosorus illigeri variety nossibianus Fairmaire 1895: 17.

Hybosorus illigeri Reiche subsp. palearcticus Endrödi 1957: 46.

Diagnosis. This species is distinguished from other species of Hybosoridae from the New World by the following combination of characters: color dark reddish-brown; length 7.0-9.0 $\mathrm{mm}$; antenna 10-segmented with 3-segmented club, first segment hollowed to receive segments 2 and 3; frontoclypeal suture not visible; labrum protruding beyond clypeus, anterior margin with 7-11 teeth; meso- and metatibiae with well-developed transverse ridge; parameres as in Figs. 4-6. An extensive redescription of the species was provided by Kuijten (1983).

Distribution (Fig. 9). Hybosorus illigeri was probably introduced to the east coast of the United States during the early 19th century (LeConte 1847). There are two prevailing hypotheses regarding the introduction of $H$. illigeri to the United States. Paulian (1944) suggested that the species probably arrived via slave ships from Africa. Howden (1970) stated that it is a

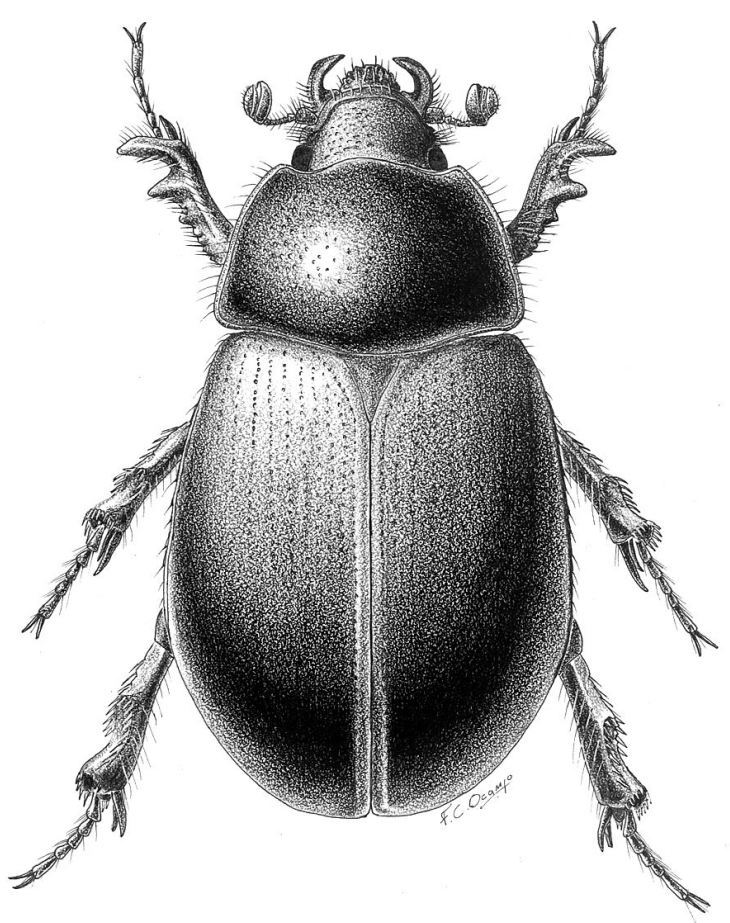

Fig. 2. Habitus of Hybosorus illigeri Reiche. 


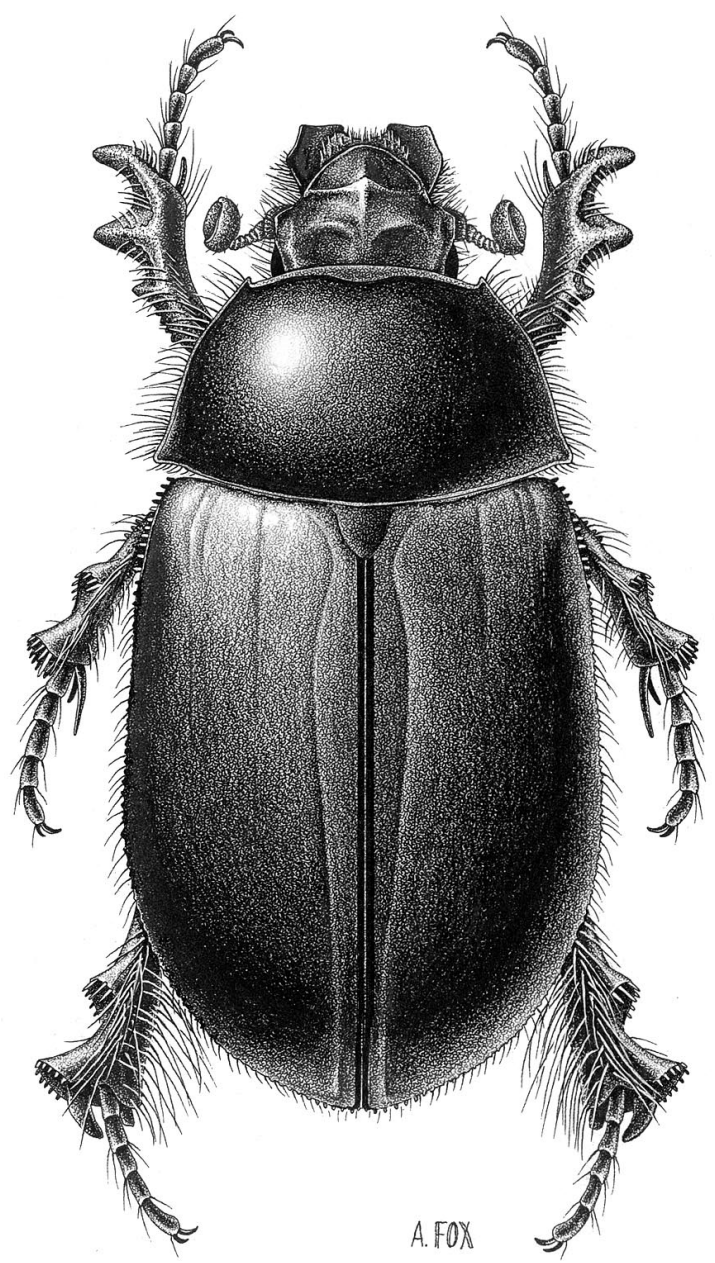

Fig. 3. Habitus of Pachyplectrus laevis LeConte.

recent European import to the United States. Woodruff (1973) recorded H. illigeri in the states of Georgia, Kentucky, and Texas. Arnold (1992) reported H. illigeri as far west as Oklahoma. I found six new state records in the United States: Arkansas, Arizona, Kansas, Missouri, New Mexico, and Virginia, which suggests that $H$. illigeri is still expanding its range. In summary, in the United States H. illigeri occurs in the states of Alabama, Arizona, Florida, Georgia, Kansas, Kentucky, Louisiana, Missouri, New Mexico, North Carolina, Oklahoma, South Carolina, Tennessee, Texas, and Virginia. It also occurs in Mexico in the states of Coahuila, Durango, Hidalgo, Jalisco (Morón et al. 1988, Navarrete-Heredia et al. 2001), Morelos, Oaxaca (Deloya 2000), Baja California Sur, Chiapas, Michoacán, Nuevo León, Sinaloa, Sonora, Tamaulipas, Veracruz, Querétaro, and Yucatán (new state records). The new records in Mexico and the United States extend the range of $H$. illigeri $350 \mathrm{~km}$ north and $690 \mathrm{~km}$ west from last reports in the literature (Arnold 1992, Deloya 2000). In the West Indies it occurs in Jamaica (Howden 1970, Ivie 1998), Bahamas, Cuba
(Kuijten 1983), and the Dominican Republic (new country record). I also found a specimen of $H$. illigeri from Venezuela collected in 1984. Four specimens were collected in Nicaragua in 1999-2000. Both constitute new country records.

In the Old World, H. illigeri has a broad distribution. It occurs in temperate areas of Europe, all of Africa except the Sahara desert, and from the Middle East to Vietnam and China. Label data indicate localities at altitudes from sea level to nearly 2,000 m. Kuijten (1983) reported a specimen from the Spanish Sierra Nevada $(2,600 \mathrm{~m})$, an area covered by snow and ice during much of the year. The distribution of $H$. illigeri in the Old World shows the high adaptability of the species to a broad range of habitats and climatological conditions. In the New World, H. illigeri potentially could expand its range as far as California, Oregon, eastern Nebraska, and southern Illinois and Indiana in the United States, and throughout South America including the temperate areas of Argentina and Chile.

Locality Records. 1,219 specimens examined.

CUBA (10): Antilla Oriente, Playa Inglés, Playa Larga. DOMINICAN REPUBLIC (25): Los Hidalgos, Monte Cristo, San Cristóbal, San Pedro de Macoris, Santo Domingo. BAHAMAS (29): GRAND BAHAMA ISLAND (17): Freeport. NEW PROVIDENCE ISLAND (4): Nassau. ANDROS ISLAND (8): San Andros. MEXICO (67): BAJA CALIFORNIA SUR (2): Miraflores. CHIAPAS (2): Cintalapa (4 miles E). DURANGO (4): San Ignacio. JALISCO (23): Chamela, Estación Chamela, Tucxacuesco. MICHOACÁN (5): Aquila. NUEVO LEÓN (11): Monterrey. SINALOA (1): Vado Hondo. SONORA (2): Rosario de Tezopaco. TAMAULIPAS (15): Ciudad Victoria, San Fernando. VERACRUZ (1): La Tinaja (13 km E). QUERÉTARO (1): Jalpán de Serra. YUCATÁN (2): Chichen Itza, Xcalacoop. NICARAGUA (4): LEÓN (1): Los Lechecuagos. MASAYA (3): Las Flores. U.S.A. (1100): ALABAMA (32): Chewacla State Park (4 miles SW), Decatur, Gulf State Park, Houston County, Mobile, Mobile-Dog River, West Blocton. ARIZONA (10): Amado, Douglas (8 km E). ARKANSAS (49): Brinkley. FLORIDA (327): Alachua, Ana Marie Is., Archbold Biological Station, Bahia Honda State Park, Boca Raton, Boynton Beach, Broward Co., Clermont, Daytona Beach, Dickinson State Park, Everglade City, Everglades National Park, Florence, FL, City (11 km SW), Hummock State Park, Holly Hill, Homestead (6 miles N), Jacksonville, Key Largo, Miami, Ocala, Old Town (3 miles N), Palmdale, Palm Bach, Panacea (10 miles S), Polk Co., Quincy, Quincy (15 miles SW), Tallahassee (17 miles N). GEORGIA (220): Albany, Athens, Beachton, Clark Co., Heards Pond, Moultrie, Prattsburg, Tomasville, Smithville, Wheeler County, KANSAS (5): Greenburg (5 miles S). LOUISIANA (83): Monroe, New Iberia, Shreveport, St. Landry Park, Vermilion County, MISSISSIPPI (32): Copiah County, Gulfport, Moss Point, Oxford, Purvis (3 miles NW), Rolling Fork, Scott Bol County, Stone County, Van Cleave (11 miles NW), Washington County, Yazoo County, No data. MISSOURI (19): Greenwood, Ironton, Lanton, Pilar Bluff, Steelville, 

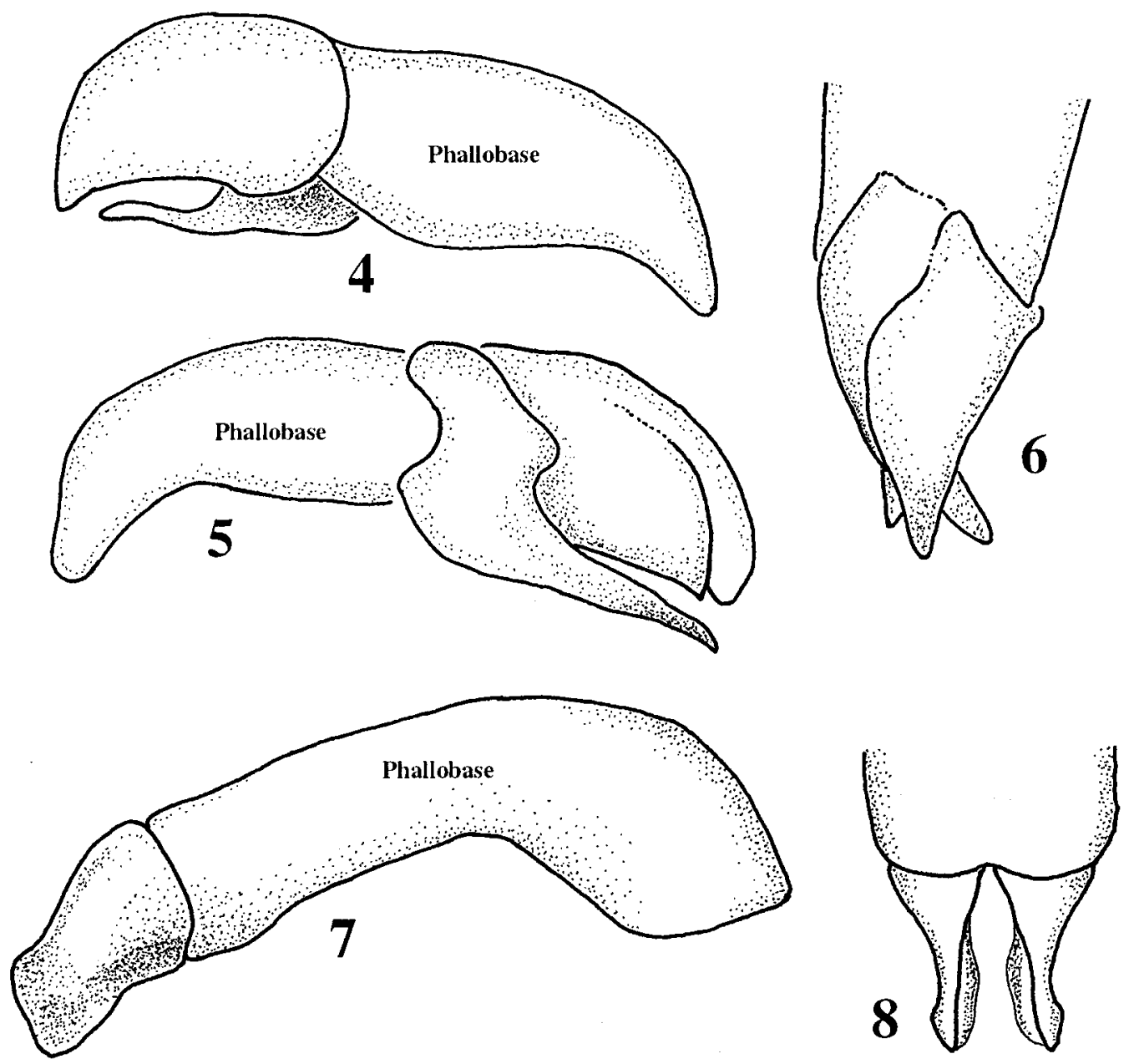

Figs. 4-8. Male genitalia, lateral and caudal views. 4-6: Hybosorus illigeri. 7-8: Pachyplectrus laevis.

Sikeston, Vernon County, No data. NEW MEXICO (4): Carlsbad, Eddy County, Mescalero Dunes. NORTH CAROLINA (2): Cherokee, Kill Devil Hill. OKLAHOMA (52): Clinton, E. Wagoner (14 miles E), Foss, Lake Texoma, Oklahoma City, Texoma State Park, Thackerville. SOUTH CAROLINA (80): Allendale, Blackville, Clemson, Florence, Meredith, St. George. TENNESSEE (6): Pulaski, Springhill. TEXAS (178): Austin, Bedford, Big Bend, Brewster County, Brazos County, Bulverde, Canyon Lake (5 miles E), Cold Spring, Comanche, Dryden, Duval, Duval County, Elkhart (10 miles SW), Flynn (5 miles N), Ft. Stockton, Greenville, Guadalupe Mts. National Park, Hidalgo, Houston, Kermit, Kiote $(3 \mathrm{~km} \mathrm{E})$, Lake Brownwood State Park, Lampasas, Laguna Park, Laredo, Loma Alta (3 miles W), Lubbock, Luling (8 km S), Medina County, New Braunfels, Nueces County, Oakville, Pleasanton, Presidio, Sinton, Stephenville, The Woodlands, Three Rivers, Town Bluff. VIRGINIA (1): No data. VENEZUELA (1): ZULIA: Distrito Perija, Tacuco.
Temporal Distribution. February (2), April (17), May (238), June (575), July (90), August (40), September (3), and October (4).

Remarks. In his revision of the genus Hybosorus, Kuijten (1983) provided a summary of the nomenclatorial history $H$. illigeri. The intricate nomenclatorial problems of the type-species were partially solved by Landin (1964) and finally by Allsopp (1982) when he proposed the conservation of the combination $\mathrm{Hy}$ bosorus illigeri Reiche. Here I summarize the nomenclatorial history of $\mathrm{H}$. illigeri.

In 1803, Illiger (1803) described Scarabaeus arator. MacLeay (1819) subsequently erected the generic name Hybosorus for H. illigeri. Reiche (1853) realized that Scarabaeus arator Illiger is a junior primary homonym of Scarabaeus arator Fabricius 1775, and he proposed the new name $H$. illigeri. At the same time, Reiche synonymized H. laportei Westwood 1845 and Hybosorus thoracicus Westwood 1845 with $H$. illigeri. Hybosorus roei Westwood 1845 was synonymized by Arrow (1912); H. pinguis Westwood 1845 was synonymized by Endrödi (1957); and H. carolinus LeConte 


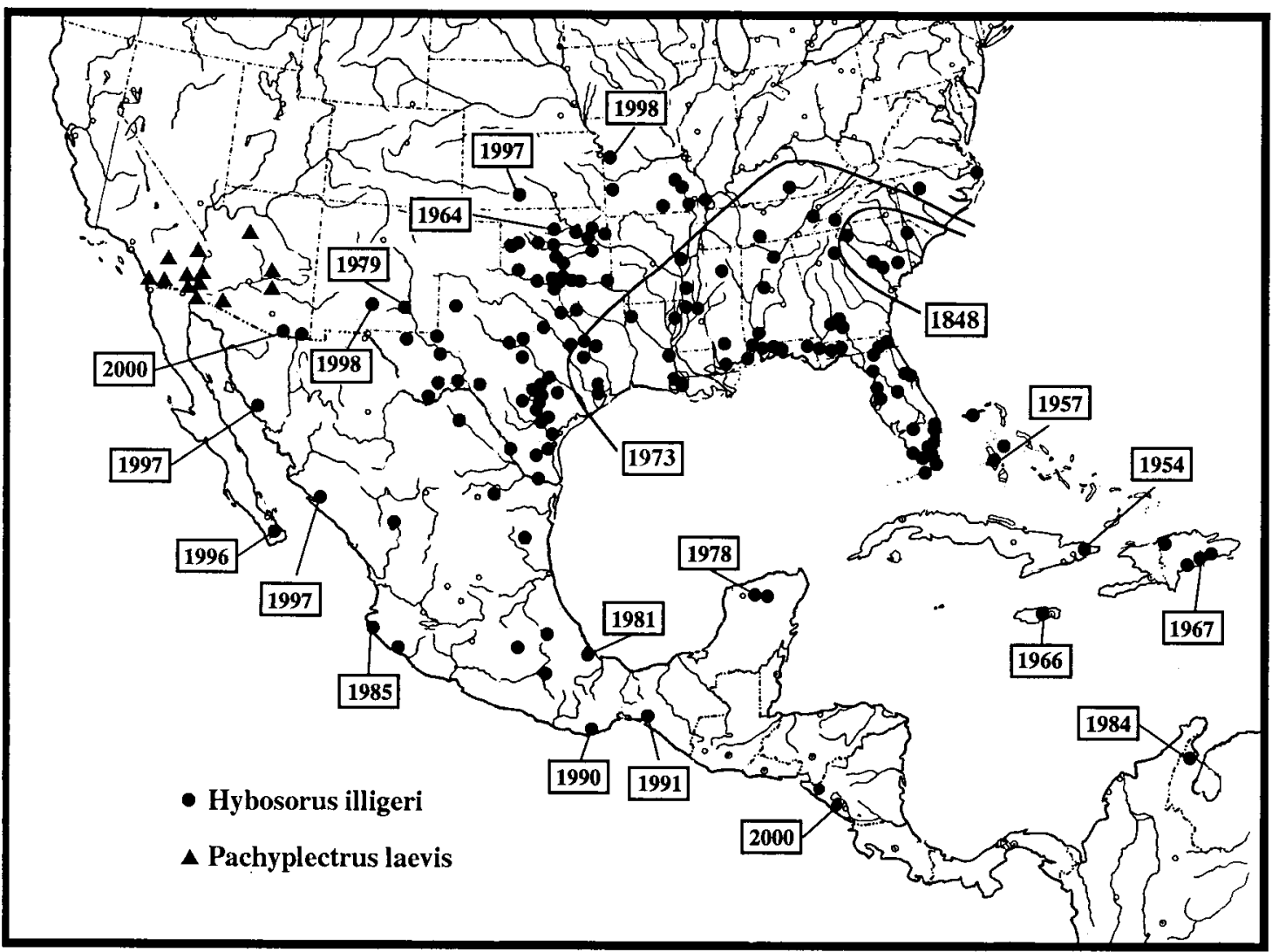

Fig. 9. Distribution of Hybosorus illigeri and Pachyplectrus laevis in the New World. Dates represent when specimens of Hybosorus illigeri were collected.

1847 was synonymized by LeConte (1862). All these names predate $H$. illigeri Reiche and so they should seemingly have priority over it. Kuijten (1983) reestablished $H$. laportei Westwood 1845 as a valid species within the genus Hybosorus and synonymized $\mathrm{H}$. nitidus Lansberge 1882, H. illigeri variety nossibianus Fairmaire 1895, and H. illigeri subs. palearticus Endrödi 1957 with H. illigeri. Allsopp (1982) (restated by Kuijten 1983) proposed the conservation of $H$. illigeri in accordance with Article 79 (b) of the International Code of Zoological Nomenclature because the species has been known as "illigeri" or "arator" for nearly 150 yr (Scarabaeus arator must be rejected because it is a junior primary homonym of S. arator F. (Scarabaeidae: Dynastinae). The name Hybosorus oblongus Dahlbom was used by Gemminger and Harold (1869), is probably a nomen nudum (Woodruff 1973, Kuijten 1983), and has since disappeared from the literature; it is also a nomen oblitum (Kuijten 1983).

Biology. Specimens of $H$. illigeri were collected at light, in carrion, and in dung (Paulian 1941, Paulian and Baraud 1982, Kuijten 1983, Rozas et al. 1991). Rozas et al. (1991) observed H. illigeri feeding on other scarabaeoids (Aphodius, Euoniticellus, and Onthophagus species) and on other H. illigeri. The same predatory habits were observed by Rozas et al. (1991) at lights where adults fed on the hydrophilid Helochares lividus (Forster).

The presence of $H$. illigeri on dung may be a strategy for its predatory habits. Apparently H. illigeri comes to dung to feed on other insects, but it does not feed on dung. Like other hybosorids (Coilodes castaneus Westwood, Hybosorus laportei Westwood, Phaeochrous emarginatus Castelnau, and several species of Phaeochroops Candèze), H. illigeri is also attracted to carrion. Hybosorus illigeri is sometimes very abundant (Woodruff 1973) and I have seen long series collected at light.

Adults of $H$. illigeri were recently observed in the state of Florida in golf courses emerging from subterranean shelters (Paul Skelley, personal communication). The use of subterranean shelters by adult hybosorids was also observed in Phaeochrous species (Kuijten 1978).

The larvae of $H$. illigeri are undescribed. The larvae of other hybosorids were found associated with roots (Chaetodus sp.) or in decomposing plant material (Cryptogenius fryi Arrow) (Costa et al. 1988), but very little is known about their biology. 


\section{Pachyplectrus LeConte 1874}

Type Species. Pachyplectrus laevis LeConte 1874.

\section{Pachyplectrus laevis LeConte 1874}

(Figs. 3, 7-9)

\section{Pachyplectrus laevis LeConte 1874: 54.}

Diagnosis. This species is distinguished from other species of Hybosoridae by the following combination of characters: Color testaceous or brown; length 4.8$6.9 \mathrm{~mm}$; antenna 10-segmented with 3-segmented club, first segment hollowed to receive segments 2 and 3 ; fronto-clypeal suture complete, with median pyramidal tubercle; meso- and metatibiae with well-developed, transverse ridge; parameres as in Figs. 7-8.

Redescription. Length $4.8-6.9 \mathrm{~mm}$. Width $2.5-3.5$ $\mathrm{mm}$. Color dorsally and ventrally testaceous or brown. Head. Dorsal surface glabrous and smooth. Frons with broad, sinuate, transverse impression. Frontoclypeal suture complete, with median pyramidal tubercle. Clypeus with apex rounded, margin slightly reflexed and setose. Labrum rounded; lateral margins rounded, apex at middle with emargination and with apical fringe of fine, dense setae. Mandible large (1.2 times clypeal length), external edge broadly rounded, dorsal surface smooth, slightly concave, with dorsally projecting sub-apical tooth. Labial surface smooth, with long, slender setae arising from margins. Antenna 10segmented; scape subequal in length to segments $2-7$, strongly notched, with 10-20 long setae on dorsal surface; segment 2 globose, with 5-7 long setae on dorsal surface; segments 3-7 wider than long; club 3-segmented, rounded, basal segment cupuliform, completely receiving penultimate and ultimate segments. Pronotum. Surface smooth, glabrous, convex, wider at base; weak bead present on all margins; basal and lateral margins rounded, lateral margins convergent toward apex; posterior angle sharp. Scutellum. Surface smooth, glabrous, subtriangular. Elytra. Surface smooth, glabrous, at middle slightly wider than pronotum. Sutural margin with stria; lateral margin with two striae; marginal striae abbreviated at base, inner marginal stria shorter than outer stria. Epipleuron with ventral surface flat and tapering from humeral angle toward sternite 1 , finally serrulate. Venter. Prosternal surface smooth, biconcave; anterior margin bisinuate, anterior angle acute. Prosternal shield with medial process poorly developed, pointed. Mesosternal surface rugose. Metasternal surface smooth, posteriorly concave to partially receive metafemur. Proespisternal surface smooth, anteriorly and laterally with long, slender setae. Mesepisternum triangular. Legs. Coxae, trochanters, and femora with moderate to dense pilosity. Metatrochanter with posterior tooth at apex. Femora robust; profemur 2.0 times longer than wide; mesofemur 2.2 times longer than wide; metafemur 1.8 times longer than wide. Protibia with three large, apical teeth, apical tooth larger than medial and basal teeth, medial tooth larger than basal; 3-4 denticles on basal third. Meso- and metatibiae with welldeveloped, transverse ridge; median surface flattened, with long, slender setae; apical margin well-developed, semicircular; transverse ridge and apical margin with series of short, thick, round-tipped setae arising from medial surface. Mesotibial spurs semicircular in cross section, apices acuminate; medial spur longer than tarsomeres one and two together; external spur slightly longer than tarsomere 1. Metatibial spur broad, shovel-like, ventrally flattened; external spur 0.3-0.5 longer than medial. Parameres. Figs. 7-8.

Distribution (Fig. 9). Pachyplectrus laevis is found in the southwestern United States.

Locality Records. Fifty specimens examined.

U.S.A.: ARIZONA (7): Theodore Roosevelt Lake; Superior ( 3 miles W), Verde River, Tacna. CALIFORNIA (43): Glamis, Glamis ( 1 mile W, 1.3 miles W, 3.5 miles NW, 2 miles N), Ogilby (3.5 miles W), Blythe (18 miles W), Hopkins Well, Long Canyon, Mojave River, Yermo, Borego, San Diego.

Temporal Distribution. January (1), March (7), April (30), May (7).

Remarks. Pachyplectrus laevis is an uncommon species. It occurs in dry, sandy areas of Arizona, southern California, and probably northwest Mexico. Some specimens were collected under carrion and owl pellets. Most of the specimens were collected at night on the soil surface. Adults are not attracted to lights (William Warner, personal communication). Larvae of $P$. laevis are unknown.

\section{Acknowledgments}

I am grateful to the curators and collection mangers who made specimens available to me for this study. I thank Brett Ratcliffe and Mary Liz Jameson (University of NebraskaLincoln) for their guidance in preparing the manuscript. This project was supported by an NSF/PEET grant (DEB9712447) to Brett Ratcliffe and Mary Liz Jameson and by a NSF Biotic Surveys and Inventory grant (DEB 9870202) to Brett Ratcliffe.

\section{References Cited}

Allsopp, P. G. 1982. Hybosorus illigeri Reiche, 1853 (Insecta, Coleoptera): proposed conservation by use of the plenary powers. Z. N. (S) 2296. Bull. Zool. Nom.39: 218-219.

Arnold, D. C. 1992. The scarab beetle Hybosorus illigeri (Coleoptera: Scarabaeidae: Hybosorinae) in Oklahoma. J. Kans. Entomol. Soc. 65: 92.

Arrow, G. J. 1912. Scarabaeidae: Pachypodinae, Pleocominae, Aclopinae, Glaphyrinae, Ochodaeinae, Orphninae, Idiostominae, Hybosorinae, Dynamopinae, Acanthocerinae, Troginae. Coleopterorum Catalogus pars 43. W. Junk, Berlin.

Costa, C., S. A. Vanin, and S. A. Casari-Chen. 1988. Larvas de Coleoptera do Brasil. Museu de Zoologia, Universidade de Sao Paulo, Sao Paulo.

Deloya, C. 2000. Escarabajos exóticos (Coleoptera: Scarabaeidae) para la fauna de los estados de Morelos y Oaxaca, México. Fol. Entomol. Mex. 108: 125-126.

Endrödi, S. 1957. Hybosoridae (Coleoptera, Lamellicornia, Scarabaeidae). Exploration du Parc National Upemba, Mission de G. F. de Witte 46: 43-49.

Fabricius, J. C. 1775. Systema entomologiae, sistens insectorum classes, ordines, genera, species adictis synonymis, lo- 
cis, descriptionibus, observationibus. Kortii, Flensburgi et Lipsiae. 832 pp.

Fairmaire, L. 1895. Descriptions de quelques Coléoptères de Madagascar. Ann. Soc. Entomol. Belg. 39: 8-40.

Gemminger, B., and E. von Harold. 1869. Catalogus Coleopterorum hucusque descriptorums y nonymicus et systematicus. Scarabaeidae: 4: 979-1346.

Howden, H. F. 1970. Jamaican Scarabaeidae: notes and descriptions (Coleoptera). Can. Entomol. 102: 1-15.

Illiger, K. 1803. Verzeichniss der in Portugal einheimischen Käfer, Lieferung1. Mag. Insek. 2: 186-258.

Ivie, M. A. 1998. Hybosoridae of the West Indies (http:/ / virgin.msu.montana.edu/WestIndies/Polyphaga/ Scarabaeoidea/index.html).

Kuijten, P. J. 1978. Revision of the Indo-Australian species of the genus Phaeochrous Castelnau, 1840 (Coleoptera: Scarabaeidae, Hybosorinae), with notes on the African species. Zool. Ver. 165: 3-40.

Kuijten, P. J. 1983. Revision of the genus Hybosorus MacLeay (Coleoptera: Scarabaeoidea, Hybosoridae). Zool. Ver. 203: 3-49.

Landin, B. O. 1964. The identity of "Scarabaeus arator Fabricius, 1775” (Col., Lamellicornia). Opusc. Entomol. 29: $117-142$.

Lansberge, J. W. 1882. Species descriptions, p. 21. In G. Révoil (ed.), Faune et Flore des Pays Comalis (Afrique Orientale). 8. Coléoptères. Compte Rendu Seanceas, Paris, 104 pp.

LeConte, J. L. 1847. Fragmenta entomologica. J. Acad. Natl. Sci. Phila. (Ser. 2) 1: 71-93.

LeConte, J. L. 1862. Classification of the Coleoptera of North America. Smithson. Misc. Coleoptera 3: 127.

LeConte, J. L. 1874. Description of new Coleoptera chiefly from the Pacific slope of North America. Trans. Am. Entomol. Soc. 5: 43-72.

MacLeay, W.S. 1819. Horae entomologicae: or essays on the annulose animals. 1: 1-60.

Morón, M. A., C. Deloya, and L. Delgado. 1988. Fauna de coleópteros Melolonthidae, Scarabaeidae y Trogidae de la región de Chamela y Jalisco, México. Fol. Entomol. Mex. 77: 313-378.
Navarrete-Heredia, J. L., L. Delgado, and H. E. FierrosLópez. 2001. Coleoptera Scarabaeoidea de Jalisco, México. Duges 8: 37-93.

Ocampo, F. C. 2000. Hybosoridae, monographic research and revision of the New World genera. (http://wwwmuseum.unl.edu/research/ entomology/obj-Hybos.htm).

Paulian, R. 1939. Les caractères larvaires des Geotrupidae (Col.) et leur importance pour la position systématique du groupe. Bull. Soc. Zool. Fr. 64: 351-360.

Paulian, R. 1941. Faune de France, 38. Coléoptères Scarabaéides. Lechevalier, Paris.

Paulian, R. 1944. Exploration du Parc National Albert, Mission G. F. de Witte (1933-1935). Hybosoridae et Trogidae (Coleoptera Lamellicornia). Inst. Parc Natl. Congo Belge 46: 1-8.

Paulian, R., and J. Baraud. 1982. Faune des Coléoptères de France. II Lucanoidea et Scarabaeoidea. Lechevalier, Paris.

Reiche, L. J. 1853. Note sur l'Hybosorus arator auctorum, et sur le Trox granulatus $\mathbf{F}$., et description d'une nouvelle espèce. Ann. Soc. Entomol. Fr. 1: 87-90.

Ritcher, P. O. 1966. White grubs and their allies. A study of North American Scarabaeoid larvae. Oregon State University Press, Corvallis.

Rozas L., J. M. Avila, and F. Sánchez-Piñero. 1991. Observación de hábitos depredadores en Hybosorus illigeri Reiche, 1853 (Coleoptera, Scarabaeoidea, Hybosoridae). Bol. As. Esp. Entomol. 15: 111-115.

Westwood, J. O. 1845. On the Lamellicorn beetles which possess exserted mandibles and labrum, and 10-jointed antennae. Trans. Entomol. Soc. Lond. 4: 155-180.

Woodruff, R. E. 1973. The scarab beetles of Florida (Coleoptera: Scarabaeidae). Part I. The Laparosticti (subfamilies: Scarabaeinae, Aphodiinae, Hybosorinae, Ochodaeinae, Geotrupinae, Acanthocerinae). Arthropods of Florida and Neighboring Land Areas 8: 1-220.

Received for publication 15 October 2001; accepted 11 February 2002. 